\title{
埋込み基礎の基礎入力動簡易評価法 SIMPLIFIED EVALUATION METHODS FOR FOUNDATION INPUT MOTION OF EMBEDDED FOUNDATION
}

\author{
鈴木 承慈*, 福和伸夫**, 護 雅 史 $^{* * *}$ \\ Tsuguyoshi SUZUKI, Nobuo FUKUWA and Masafumi MORI
}

\begin{abstract}
In this paper, we propose two simplified methods for foundation input motion of embedded foundation. The first is the least squares method based on the geometrical relationship between each part of the foundation and ground motion. The second is the weighted average method which uses the simplified evaluation for the driving force and impedance function of embedded foundation by combining the impedance function of spread foundation and ground motion. The accuracy and validity of the proposed methods are shown by comparing the results with those obtained from an existing numerical method.
\end{abstract}

\author{
Keywords : Dynamic Soil-Structure Interaction, Foundation Input Motion, Embedded Foundation, \\ Impedance, Driving Force \\ 建物と地盤との動的相互作用，基礎入力動，埋込み基礎，インピーダンス，ドライビングフォース
}

\section{1. はじめに}

近年の地震被害では、観測された地震動の強さに比較して建物の 被害が少ない例が報告されている例えば、1)。この要因として、設計で は考慮されていない建物の余力や、建物と地盤との動的相互作用効 果等が挙げられることがある。

動的相互作用効果、特に入力の相互作用効果については、観測や 実験による実証的な研究が精力的に行われており、そのメカニズム を明らかにする上で重要な知見が得られてきている。山原2)、3は、 1968 年十勝沖地震の余震観測から、一般に基礎の動きは周辺地盤よ りも小さく、その差は地動が短周期であるほど大きいことを示し、 これを入力損失と呼び、さらにその効果を理論的にも説明した。石 井・山原4 は、埋込みを有するタンクの実測記録と解析から、基礎 と地盤の伝達特性が入力損失の概念で捉えることが可能なこと、入 力損失は基礎の平面的な広がり以上に埋込み深さが重要なパラメー タであることを指摘した。安井ら5)は、1995 年兵庫県南部地震にお いて、地表面と建物基礎とで同時観測された強震記録や、激震地に 建つ建物基礎の記録とそれから逆算した自由地表面の記録を比較し た結果、建物基礎の応答は地表面に比べ、最大加速度で 3 割、最大 速度で 1 割低減されることなどを指摘した。小島ら ${ }^{6}$ は、地震動の 等価卓越振動数を用いて求めた無次元振動数を用いることにより、 入力損失効果を統一的に評価できることなどを示した。井口ら7)、 川島ら ${ }^{81}$ は、大型振動台と周辺地盤での同時地震観測記録分析から、 基礎有効入力動の低減は、地震動の振動数特性の影響を強く受ける
こと、基礎有効入力動には水平動と回転動の 2 つの成分を含み、振 動数成分に対して異なる性状を示寸ことなどを明らかにした。これ らの知見は解析的研究とも合致する例えは、9)。

動的相互作用問題は、理論解析の位置付けが高く、高度な解析手 法が活用されている反面、一般の建物の設計でこの効果を取り入れ るためには、簡便な評価手法が必要不可欠である。そうした中で、 2000 年に導入された限界耐力計算法 (以降、限耐法と表記)では、入 力地震動が工学的基盤で定義され、地盤増幅が考慮されるとともに、 動的相互作用効果を簡易に評価する方法が提示された。これによっ て、一般の建物でも動的相互作用効果を取り入れた、より実現象に 近い耐震設計が可能となった。限耐法の妥当性や精度については、 これまでに各種検討がなされている例えば、10)。基礎の埋込みによる入 力の相互作用効果については、水平方向の入力損失としてのみ評価 されており、回転動の影響は考慮されていない11)。

そこで本論では、基礎入力動の各成分を簡便に評価できる 2 つの 手法を提案する。一つは、埋込夕基礎と地動との幾何学的な関係か ら基礎入力動を評価する方法(簡易解[1])、もう一つは、埋込み基礎 のインピーダンスを、地表面基礎のインピーダンスを要素（底面、 側面）ごとに補正した上で重㸚合せて表現し、さらにそれらと地動 から評価したドライビングフォースから基礎入力動を評価する方法 (簡易解[2])である。本論では、両手法について述べるとともに、薄 層要素法と有限要素法を容積法に基づく動的サブストラクチャー法 によって結合した手法12)を用いて求めた基礎入力動 (精算解とする)

\footnotetext{
* 名古屋大学大学院環境学研究科 大学院生

** 名古屋大学大学院環境学研究科 教授.工博

*** 名古屋大学大学院環境学研究科 准教授 $\cdot$ 博士 (工学)

Grad. Student, Grad. School of Environmental Studies, Nagoya Univ. 
と比較することにより、それらの妥当性を検証する。

埋込夕基礎の基礎入力動の簡易評価法に関する既往の研究として は、インピーダンスが既知であることを前提としたIguchi ${ }^{13)}$ の近似 解析法、その手法を改良し、自由地盤の変位のみを利用して計算寸 る栗本・井口14)の手法、不整形な埋込み基礎でも評価可能な栗本・ 関15)の手法などが挙げられる。既往の研究と比較して、本論での提 案式は式の構造が比較的単純であること、また簡易解[2]については、 インピーダンスと基礎入力動を共に簡便に評価可能であることが特 徵である。

\section{2. 最小 2 乗法を用いた基礎入力動の簡易評価法（簡易解 [1]）}

本手法は、地表面基礎の基礎入力動の近似解法16)を埋込夕基礎に 拡張したものである。すなわち、基礎は剛、地盤は半無限一様とし て、剛基礎に調和地動が入射した時の基礎と地動との変位差が最小 になるという条件から基礎入力動を評価する方法である。基礎と地 動の幾何学的な位置関係から基礎入力動を簡易評価するため、本評 価法で必要と寸るパラメータは基礎寸法、地盤のせん断波速度、入 射角のみで簡便に解が得られるという特徵がある。

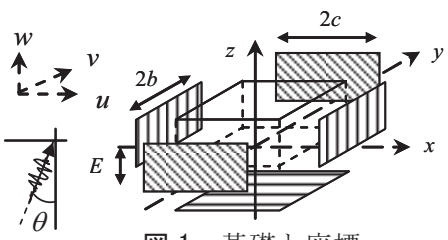

図 1 基礎と座標

解析するモデルの概念図を図 1 に示す。基礎は、基礎幅 $2 b \times 2 c$ 、 埋込み深さ $E$ の矩形剛基礎を対象とする。入射する地震動は調和振 動とし、その成分を $(u, v, w) e^{i \omega t}$ とする。以降は時間因子 $e^{i \omega t}$ を省略す る。埋込み基礎の基礎入力動は、底面図心位置で評価することとし、 ここを座標の原点とする。剛基礎の場合、その運動は 6 つの自由度 を持ち、以下のように表せる。

$$
\left\{U^{*}\right\}=\left\{\Delta_{x}^{*}, \Delta_{y}^{*}, \Delta_{z}^{*}, \Phi_{x}^{*}, \Phi_{y}^{*}, \Phi_{z}^{*}\right\}^{T}
$$

ここで、 $\Delta_{x}{ }^{*} 、 \Delta_{y}{ }^{*} 、 \Delta_{z}{ }^{*}$ は基礎変位の各軸方向の並進成分、 $\Phi_{x}{ }^{*} 、 \Phi_{y}{ }^{*} 、$ $\Phi_{z}{ }^{*}$ は各軸回りの回転成分を表す。以降では $\Delta_{x}{ }^{*} 、 \Delta_{y}{ }^{*}$ を水平動、 $\Delta_{z}{ }^{*}$ を上下動、 $\Phi_{x}{ }^{*} 、 \Phi_{y}{ }^{*}$ を回転動、 $\Phi_{z}{ }^{*}$ をねじれ動と称する。

まず、図 1 に示すように、埋込み基礎を地盤と接する 5 つの面に 分離し、これらの面の変位と地動の変位の 2 乗和の合計を以下に定 義する。

$$
\begin{aligned}
W & =\sum \int\left\{\left(\Delta_{x}^{*}-y \Phi_{z}^{*}-z \Phi_{y}^{*}\right)-u\right\}^{2} d S_{i} \\
& +\sum \int\left\{\left(\Delta_{y}^{*}+x \Phi_{z}^{*}-z \Phi_{x}^{*}\right)-v\right\}^{2} d S_{i} \\
& +\sum \int\left\{\left(\Delta_{z}^{*}+y \Phi_{x}^{*}-x \Phi_{y}^{*}\right)-w\right\}^{2} d S_{i}
\end{aligned}
$$

ここで、 $S_{i}$ は分離された基礎の各面の面積を表す。式(2)を基䃈入力 動の各成分で偏微分をとり、これを0と置くことで基礎入力動を得 る。原点が底面図心位置なので、積分は $x 、 y$ 方向には対称、 $z$ 方向に は非対称であることに注意して解くと、以下の式が得られる。

$$
\Delta_{x}^{*}=\frac{C_{0}}{A} \sum \int u d S_{i}+C_{1} E \Phi_{y}^{*}
$$

$$
\begin{aligned}
& \Delta_{y}^{*}=\frac{C_{0}}{A} \sum \int v d S_{i}+C_{1} E \Phi_{x}^{*} \\
& \Delta_{z}^{*}=\frac{C_{0}}{A} \sum \int w d S_{i} \\
& \Phi_{x}^{*}=\frac{C_{2}}{I_{x}} \sum \int\left\{y w-\left(z-C_{1} E\right) v\right\} d S_{i} \\
& \Phi_{y}^{*}=-\frac{C_{3}}{I_{y}} \sum \int\left\{x w+\left(z-C_{1} E\right) u\right\} d S_{i} \\
& \Phi_{z}^{*}=\frac{C_{4}}{I_{x}+I_{y}} \sum \int(x v-y u) d S_{i}
\end{aligned}
$$

ここで、以下に示すように、 $C_{0}$ は底面積 $A$ と表面積の比、 $C_{1}$ は深さ 方向の図心位置を表寸係数、 $C_{2} \sim C_{4}$ はそれぞれ底面の $x 、 y 、 z$ 軸周り の断面（極）2次モーメント $I_{x} 、 I_{y} 、 I_{x}+I_{y}$ と分離した基礎でのそれら の和の比を示し、全て基礎の寸法によって決まる無次元の係数であ る。

$$
\begin{aligned}
& C_{0}=A / \sum \int d S_{i} \\
& C_{1}=\frac{1}{E} \times \sum \int z d S_{i} / \sum \int d S_{i} \\
& C_{2}=I_{x} /\left\{\sum \int\left(y^{2}+z^{2}\right) d S_{i}-\left(\sum \int z d S_{i}\right)^{2} / \sum \int d S_{i}\right\} \\
& C_{3}=I_{y} /\left\{\sum \int\left(x^{2}+z^{2}\right) d S_{i}-\left(\sum \int z d S_{i}\right)^{2} / \sum \int d S_{i}\right\} \\
& C_{4}=\left(I_{x}+I_{y}\right) / \sum \int\left(x^{2}+y^{2}\right) d S_{i}
\end{aligned}
$$

式(3) (5)で示した水平動、上下動の第1項は全ての面での地動変 位の合計を基礎の表面積で平均化しており、式(6) (8)で示した回転 動、漦じれ動の第1項はモーメント平均になっている。第2項の基礎 入力動成分に掛かる係数は、基礎の深さ方向の図心位置に相当し、 水平動と回転動が連成して生じていることが分かる。また入射する 地動が水平成分のみでも側面が地動を拘束する効果で回転動が生じ ることが表現されている。

ここで、式(3) (8)で示した基礎入力動を具体的な問題に適用する。 図1に示した基礎に対し、 $x$ 方向に振動するSH波について、鉛直下方 入射と斜め入射の場合を検討する。地動の地表面での振幅を $U_{0}$ 、入 射角を $\theta$ 、地盤のせん断波速度を $V s$ とする。地表面は $z=E$ の位置にあ ることを考慮すると、地動の全変位場は以下の式で表される。

$$
u(y, z)=U_{0} \cos \left\{\frac{\omega \cos \theta}{V_{S}}(z-E)\right\} \exp \left(-i \frac{\omega \sin \theta}{V s} y\right)
$$

鉛直下方入射では、式(14)で $\theta=0$ とする。

式(14)を式(3) (8)に代入することにより、SH波が鉛直下方入射す る場合の基礎入力動は、以下のように表すことができる。

$$
\begin{aligned}
\Delta_{x}^{*}= & U_{0} C_{0}\left\{\cos \left(E / b_{e} \cdot a_{0}\right)\right. \\
& \left.+E / b_{e} \cdot\left(\sqrt{c / b}+\frac{1}{\sqrt{c / b}}\right) j_{0}\left(E / b_{e} \cdot a_{0}\right)\right\}+C_{1} E \Phi_{y}^{*} \\
\Phi_{y}^{*} \times b_{e} & =-U_{0} \frac{3 C_{3}\left(E / b_{e}\right)^{2}}{c / b}\left[\left(\sqrt{c / b}+\frac{1}{\sqrt{c / b}}\right) \frac{1-\cos \left(E / b_{e} \cdot a_{0}\right)}{\left(E / b_{e} \cdot a_{0}\right)^{2}}\right. \\
& \left.-C_{1}\left\{\frac{1}{E / b_{e}} \cos \left(E / b_{e} \cdot a_{0}\right)+\left(\sqrt{c / b}+\frac{1}{\sqrt{c / b}}\right) j_{0}\left(E / b_{e} \cdot a_{0}\right)\right\}\right]
\end{aligned}
$$


また、斜めから入射した場合の基礎入力動は以下のようになる。

$$
\begin{aligned}
\Delta_{x}^{*}= & U_{0} C_{0}\left[j_{0}\left(\frac{1}{\sqrt{c / b}} a_{0} \sin \theta\right) \cos \left(E / b_{e} \cdot a_{0} \cos \theta\right)\right. \\
+ & E / b_{e} \cdot\left\{\sqrt{c / b} \cos \left(\frac{1}{\sqrt{c / b}} a_{0} \sin \theta\right)+\frac{1}{\sqrt{c / b}} j_{0}\left(\frac{1}{\sqrt{c / b}} a_{0} \sin \theta\right)\right\} \quad(17) \\
\times & \left.j_{0}\left(E / b_{e} \cdot a_{0} \cos \theta\right)\right]+C_{1} E \Phi_{y}^{*} \\
\Phi_{y}^{*} \times b_{e}= & -U_{0} \frac{3 C_{3}\left(E / b_{e}\right)^{2}}{c / b}\left[\left\{\sqrt{c / b} \cos \left(\frac{1}{\sqrt{c / b}} a_{0} \sin \theta\right)+\frac{1}{\sqrt{c / b}} j_{0}\left(\frac{1}{\sqrt{c / b}} a_{0} \sin \theta\right)\right\}\right. \\
& \times \frac{1-\cos \left(E / b_{e} \cdot a_{0} \cos \theta\right)}{\left(E / b_{e} \cdot a_{0} \cos \theta\right)^{2}}-\frac{C_{1}}{E / b_{e}} j_{0}\left(\frac{1}{\sqrt{c / b}} a_{0} \sin \theta\right) \cos \left(E / b_{e} \cdot a_{0} \cos \theta\right) \\
& \left.-C_{1}\left\{\sqrt{c / b} \cos \left(\frac{1}{\sqrt{c / b}} a_{0} \sin \theta\right)+\frac{1}{\sqrt{c / b}} j_{0}\left(\frac{1}{\sqrt{c / b}} a_{0} \sin \theta\right)\right\} j_{0}\left(E / b_{e} \cdot a_{0} \cos \theta\right)\right]
\end{aligned}
$$

$$
\begin{aligned}
\Phi_{z}^{*} \times b_{e}= & i U_{0} \frac{3 C_{4} \sqrt{c / b}}{1+(c / b)^{2}}\left[j_{1}\left(\frac{1}{\sqrt{c / b}} a_{0} \sin \theta\right) \cos \left(E / b_{e} \cdot a_{0} \cos \theta\right)\right. \\
& +E / b_{e} \cdot\left\{\sqrt{c / b} \sin \left(\frac{1}{\sqrt{c / b}} a_{0} \sin \theta\right)+\frac{1}{\sqrt{c / b}} j_{1}\left(\frac{1}{\sqrt{c / b}} a_{0} \sin \theta\right)\right\} \\
& \left.\times j_{0}\left(E / b_{e} \cdot a_{0} \cos \theta\right)\right]
\end{aligned}
$$

ここで、 $b_{e}$ は基礎底面と同面積の等価正方形基礎の基礎幅であり、 $a_{0}$ は無次元振動数で $a_{0}=\omega b_{e} / V s 、 j_{0}(\cdot) 、 j_{1}(\cdot)$ は球ベッセル関数で以下 のように表される。

$$
\begin{aligned}
& j_{0}(z)=\frac{\sin z}{z} \\
& j_{1}(z)=\frac{\sin z}{z^{2}}-\frac{\cos z}{z}
\end{aligned}
$$

\section{3. インピーダンスを重みとした基礎入力動簡易評価法（簡易解 [2]）}

無質量剛基礎が地震波を受けた時の基礎拘束力であるドライビン グフォースを $F_{H} 、 F_{R}$ とする。矩形基礎の場合、インピーダンスの水 平 $\left(K_{H H}\right)$ 、回転 $\left(K_{R R}\right)$ 、水平一回転連成 $\left(K_{H R}=K_{R H}\right)$ 成分とドライビング フォースから、基礎入力動は以下の式で表される。

$$
\left\{\begin{array}{l}
\Delta_{x}^{*} \\
\Phi_{y}^{*}
\end{array}\right\}=\left[\begin{array}{ll}
K_{H H} & K_{H R} \\
K_{R H} & K_{R R}
\end{array}\right]^{-1}\left\{\begin{array}{l}
F_{H} \\
F_{R}
\end{array}\right\}
$$

本手法では、ドライビングフォースとインピーダンスを簡易に評 価し、式(22)から基䃈入力動を計算する。ドライビングフォースは 地動の変位を用いて計算するため、本手法は基礎のインピーダンス を用いて重み付けされた地動変位から基礎入力動を簡易に計算する ことに相当する。本検討では、評価対象を無次元振動数 $a_{0}=3$ 以下、 埋込夕深さ比 $E / b_{e}=1$ 以下、アスペクト比は $0.1 \leqq c / b \leqq 10.0$ とする。

\section{1 インピーダンスの簡易評価}

埋込み基礎のインピーダンスの簡易評価には、護ら 17)の手法を拡 張したものを用いる。すなわち、地表面基䃈のインピーダンスは既 知であるとし、埋込み基礎のインピーダンスを底面要素と側面要素 の和で計算する。底面要素には地表面基礎のインピーダンスを用い、 側面要素は同じ地表面基礎のインピーダンスを側面の形状に合わせ て補正したものに係数 $\alpha$ を乗じて表す。護らの提案式は検討範囲に おいて埋込み基礎のインピーダンスを適切に表現しているが、式中 に表れる係数について物理的な意味にまで十分には言及していない。 そこで本論では、係数の定性的な意味が表現できるように護らの手 法を修正して用いる。
式(23) (26)にインピーダンスの簡易評価式を、図2に各インピー ダンスを足し合わせる側面要素の概念図を示す。

$$
\begin{aligned}
& K_{H H}={ }^{b} \gamma_{1} K_{H H}^{b}+2 \alpha_{H H}\left(s 1 \gamma_{1} K_{H H}^{b}+{ }^{s 2} \gamma_{3} K_{V V}^{b}\right) \\
& K_{V V}={ }^{b} \gamma_{3} K_{V V}^{b}+2 \alpha_{V V}\left({ }^{s 1} \gamma_{2}+{ }^{s 2} \gamma_{2}\right) K_{H H}^{b} \\
& K_{R R}=\gamma_{5} K_{R R}^{b}+2 \alpha_{R R}\left\{\left({ }^{s 1} \gamma_{1} K_{H H}^{b}+{ }^{s 2} \gamma_{3} K_{V V}^{b}\right) \times\left(\frac{E}{2}\right)^{2}+{ }^{s 2} \gamma_{2} K_{H H}^{b} c^{2}\right\} \\
& K_{H R}=2 \alpha_{H H}\left(s 1 \gamma_{1} K_{H H}^{b}+{ }^{s 2} \gamma_{3} K_{V V}^{b}\right) \frac{E}{2}+2 \alpha_{V V}{ }^{s 2} \gamma_{2} K_{H H}^{b} c
\end{aligned}
$$

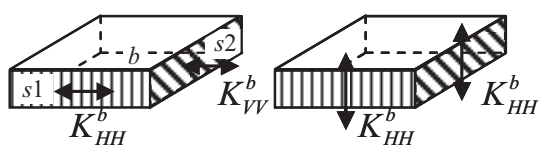

(a) 水平

(b) 上下

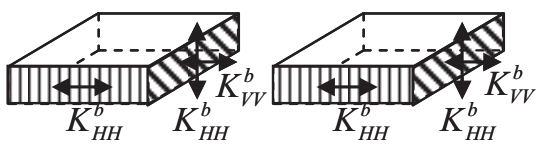

(c) 回転

(d) 水平一回転連成

図 2 側面要素の足し合わせ

ここで、 $K_{H H}^{b} 、 K^{b}{ }_{V V} 、 K^{b}{ }_{R R}$ は地表面基礎の水平、上下、回転インピ ーダンスであり、本手法では既知であるとしている。 $\alpha$ 添え字は インピーダンスの成分を表す。 恃、杉本ら 18$)$ にる地表面基礎のイ ンピーダンスの形状補正係数である。杉本らは、直接基礎の浮上り に伴うインピーダンスの変化を考慮するために、基礎形状の変化と インピーダンスの変化の関係を形状補正係数 $\gamma$ して提案している。 この手法では、基礎のアスペクト比と面積の変化の両方が考慮でき る。表 1 に、杉本らの手法による係数の一覧を、図3にその概念図を 示す。ここで、 $\eta$ は形状変化前と後での等価面積を持つ正方形基礎 の基礎幅の比、入は形状変化後のアスペクト比である。本論では、 底面要素に使用した地表面基礎のインピーダンスから側面要素を形 状通りに補正するために、本手法を適用した。なお、式(23) (26)に ある旧右下付添字は表1に示した補正するインピーダンスの成分で ある。また、yの左上付添字は、戝2 に示すように分離した埋込み基 礎の面の種類を表す。すなわち、bは底面、 $s 1$ は側面の加振平行面、 $s 2$ は側面の加振直交面を表している。さらに、この区別によって表 1

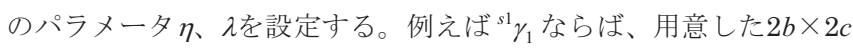
の地表面基礎を $s 1$ の形状、寸なわち $E \times 2 c$ に補正するので、パラメー タを $\eta=\sqrt{2 c E / 4 b c} 、 \lambda=E / 2 c$ として $\gamma_{1}$ を計算するという意味になる。

これによって、 $\alpha$ を純粋に地盤の重複を補正する係数と位置づけ ることが可能となる。すなわち、実部は、応力球根の観点から、側 面要素による影響と底面要素による影響が重複する領域が生じるた め、底面と側面のインピーダンスの単純和では過大となる。それを 補正するための係数が $\alpha$ でる。

係数 は、埋込み深さ比の異なる複数の正方形埋込み基礎に対し てインピーダンスが最もよく精算解と合うように、最小 2 乗法によ るフィッティングによりそれぞれ推定し、さらに得られた $\alpha$ を埋込 み深さ比の関数として表現した。実部についての推定結果を図4に 
示す。これを見ると、フィッティング結果は、共通して埋込みが深 くなるに従って増加する傾向にある。また、推定式 $\alpha_{H H} 、 \alpha_{V V} 、 \alpha_{R R}$ は十分に元のフィッティング結果を再現できていることが分かる。

なお、水平一回転連成の実部の係数については、 $\alpha_{H H} 、 \alpha_{V V}$ を用い て良く推定できたことから、それらを用いることとした。

一方、インピーダンスの虚部は、逸散減衰を表しており、接地面 積に依存するため、側面と底面を単純に足した場合でも過大となら ないことから、係数を 1.0 とした。ただし、水平一回転連成について は、単純和の場合、埋込み深さ比が1以下の検討対象範囲では過大 評価となったため、最も精算解と対応が良かった 0.5 を用いることと した。ただし、埋込み深さ比が1以上になると単純和の方が良い対 応を示寸傾向にある。これは、水平一回転連成の虚部が、埋込夕深 さ比1程度では他の成分と比較して值が非常に小さく、単純和では 評価できないためと推察される。係数 $\alpha$ の覧をまとめて表 2 に示す。

表 1 基礎形状の補正係数

\begin{tabular}{|c|c|c|}
\hline & 実部 & 虚部 \\
\hline$K_{11}$ & $\gamma_{1}=\eta \times\left(0.55 \lambda^{0.37}+0.45 \lambda^{-0.31}\right)$ & $\gamma_{1}=\eta^{2}$ \\
\hline$K_{22}$ & $\gamma_{2}=\eta \times\left(0.48 \lambda^{0.28}+0.52 \lambda^{-0.38}\right)$ & $\gamma_{2}=\eta^{2}$ \\
\hline$K_{33}$ & $\gamma_{3}=\eta \times\{0.205(\sqrt{\lambda}+1 / \sqrt{\lambda})+0.59\}$ & $\gamma_{3}=\eta^{2}$ \\
\hline$K_{44}$ & $\gamma_{4}=\eta^{3} \times \lambda^{0.61}$ & $\gamma_{4}=\eta^{4.35} \times \lambda^{1.06}$ \\
\hline$K_{55}$ & $\gamma_{5}=\eta^{3} \times \lambda^{-0.86}$ & $\gamma_{5}=\eta^{4.35} \times \lambda^{-1.05}$ \\
\hline$K_{66}$ & $\gamma_{6}=\eta^{3} \times 0.49(\lambda+1 / \lambda)$ & $\begin{array}{c}\gamma_{6}=\eta^{4.3} \times 0.66 \lambda^{-0.9}(\lambda<0.6) \\
\gamma_{6}=1.0 \quad(\lambda \geq 0.6)\end{array}$ \\
\hline
\end{tabular}
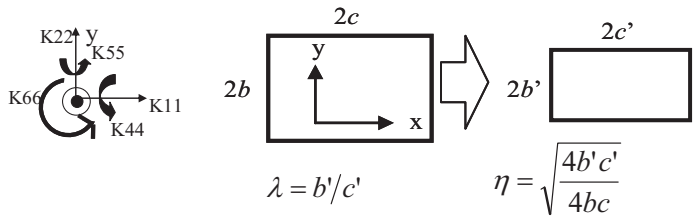

図 3 形状補正の概念目

表 2 地盤重複効果の補正係数

\begin{tabular}{|l|c|c|}
\hline & 実部 & 虚部 \\
\hline 水平 $\alpha_{H H}$ & $-0.25 \times\left(E / b_{e}\right)^{2}+0.4 \times E / b_{e}+0.08$ & 1.0 \\
\hline 上下 $\alpha_{V V}$ & $-0.03 \times\left(E / b_{e}\right)^{2}+0.13 \times E / b_{e}$ & 1.0 \\
\hline 回転 $\alpha_{R R}$ & $-0.4 \times\left(E / b_{e}\right)^{2}+1.23 \times E / b_{e}$ & 1.0 \\
\hline 連成 & $\alpha_{H H} 、 \alpha_{V V}$ を使用 & 0.5 \\
\hline
\end{tabular}

\section{2 ドライビングフォースの簡易評価}

ドライビングフォースを求める概念図を図5に示す。ドライビン グフォースは、切欠き型サブストラクチャー法の概念 ${ }^{19)}$ に基づき、 非切欠き地盤における入力動を利用する。3.1項と同様に基礎を底面、 側面要素に分離して考える。式(27)、(28)に示すように、 $F_{H}$ は底面、 側面要素の水平インピーダンスにその位置での地動変位を乗じ、底 面切欠き力を差し引いて求め、 $F_{R}$ は側面要素の水平、上下インピー ダンスに地動変位と基礎底面からの腕の長さを乗じて簡易に評価し た。式(28)では、切欠き地盤の側面摩擦力は考慮していない。側面 要素のインピーダンスに腕の長さを乗じたものは式(26)に相当する ため、それを用いて式(28)を表現している。なお、眓5にある $K_{H H}^{s}$ は、側面要素の水平インピーダンスを表し、式(23)の第2項を意味す る。

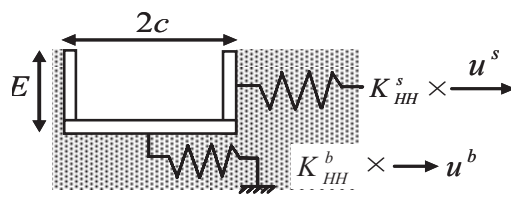

図 5 ドライビングフォースの概念図

$$
\begin{aligned}
& F_{H}={ }^{b} \gamma_{1} K_{H H}^{b} \times u^{b}+2 \alpha_{H H}\left({ }^{s 1} \gamma_{1} K_{H H}^{b}+{ }^{s 2} \gamma_{3} K_{V V}^{b}\right) \times u^{s}-P_{H} \\
& F_{R}=K_{H R} \times u^{s}
\end{aligned}
$$

ここで、 $u^{b}$ は底面位置での地動変位であり、SH波の鉛直下方入射の 場合、式(29)で表される。 $u^{s}$ は側面位置での地動の平均変位であり、 式(29)を深さ方向に平均して求める。 $P_{H}$ は、底面位置での切欠き力 であり、Gを地盤のせん断剛性とすると式(31)で表される。

$$
\begin{aligned}
& u^{b}=U_{0} \cos \left(E / b_{e} \cdot a_{0}\right) \\
& u^{s}=U_{0} j_{0}\left(E / b_{e} \cdot a_{0}\right) \\
& P_{H}=4 U_{0} G b_{e} a_{0} \sin \left(E / b_{e} \cdot a_{0}\right)
\end{aligned}
$$

\section{4. 精算解と簡易解の比較}

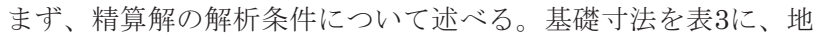
盤物性を表4に示す。基礎の埋込夕部分は6面体SOLID要素を用いて モデル化し、要素サイズは $1 \mathrm{~m} \times 1 \mathrm{~m} \times$ 埋込み深さの $1 / 4$ を目安に均等 に分割した。簡易解[2]で用いる既知とした地表面基礎のインピーダ

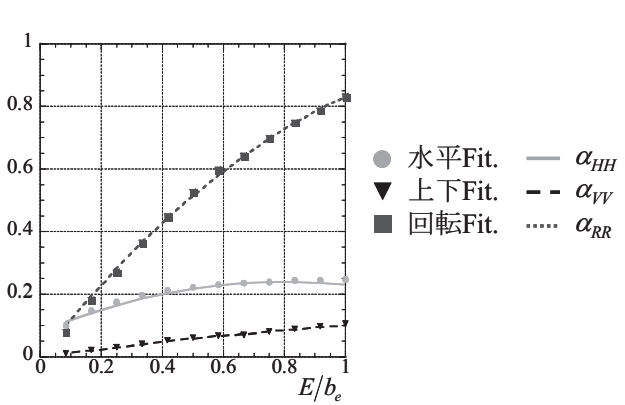

図 4 地盤重複効果の係数

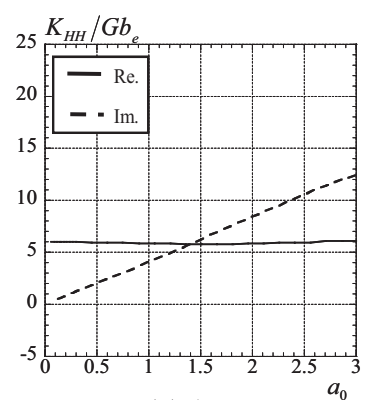

(a) 水平

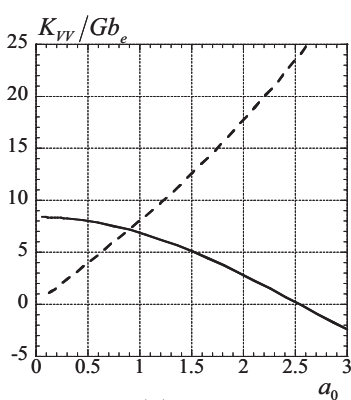

(b) 上下

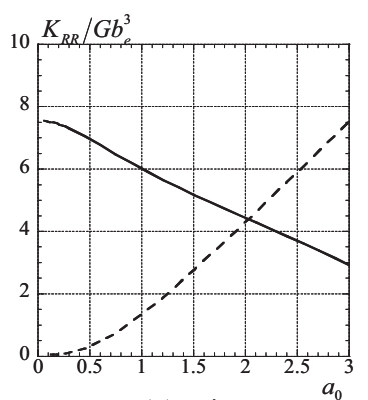

(c) 回転

図 6 地表面基䃈のインピーダンス 
表 3 基礎形状

\begin{tabular}{|c|c|c|c|c|}
\hline & case-1 & case-2 & case-3 & case-4 \\
\hline $2 b(\mathrm{~m})$ & 24 & 24 & 30 & 18 \\
\hline $2 c(\mathrm{~m})$ & 24 & 24 & 19.2 & 32 \\
\hline$E(\mathrm{~m})$ & 4 & 12 & 12 & 12 \\
\hline$c / b$ & 1.00 & 1.00 & 0.64 & 1.78 \\
\hline$E / b{ }_{e}$ & 0.33 & 1.00 & 1.00 & 1.00 \\
\hline \multicolumn{5}{|c|}{ 表 4 地盤条件 } \\
\begin{tabular}{|c|c|c|c|}
\hline$V s(\mathrm{~m} / \mathrm{s})$ & $\rho\left(\mathrm{t} / \mathrm{m}^{3}\right)$ & $v$ & $h$ \\
\hline 250 & 1.8 & 0.45 & 0.03 \\
\hline
\end{tabular}
\end{tabular}

(半無限一様地盤)

ンスは、平面を $48 \times 48$ 要素に分割したものを用いた。地盤の分割数 は地表面から埋込み深さの $1 / 16 \mathrm{~m} \times 40 、 1 \mathrm{~m} \times 50 、 2 \mathrm{~m} \times 50 、 4 \mathrm{~m} \times 25$ とした。図6に簡易解[2]に使用した地表面基礎のインピーダンスを 示す。

図 6 8 の縦軸は、無次元化したインピーダンスの水平 $\left(K_{H H} / G b_{e}\right)$ 、 上下 $\left(K_{V V} / G b_{e}\right)$ 、回転 $\left(K_{R R} / G b_{e}{ }^{3}\right)$ 、水平一回転連成 $\left(K_{H R} / G b_{e}{ }^{2}\right)$ であり、 図 11 13 の縦軸は、自由地盤の地表面での応答 $\left(U_{0}\right)$ に対する基礎底 面での水平 $\left(\Delta_{x}{ }^{*}\right)$ 、回転 $\left(\Phi_{y}{ }^{*} \times b_{e}\right)$ 、水じれ $\left(\Phi_{z}{ }^{*} \times b_{e}\right)$ 応答の伝達関数で ある。横軸は全て無次元振動数 $a_{0}$ である。

簡易解[2]では、簡易評価式(23) (26)によるインピーダンスと、簡 易評価式(27)、（28）によるドライビングフォースを使用している。 そこで、まず、それらの評価結果を精算解と比較してその妥当性を 検証する。次に、簡易解[1]と簡易解[2]の基礎入力動を精算解と比較 する。

図 7 に埋込み深さ比 $\left(E / b_{e}\right)$ を、図 8 に基礎平面のアスペクト比 $(c / b)$ をパラメータとした、簡易解[2]で使用するインピーダンスの精算解 との比較結果を示す。(a)水平や(d)水平一回転連成の実部における高 振動数での付加質量効果による減少が表現できていないものの、他 は精算解と比較的良く対応している。図 8 のアスペクト比の影響は、 (a)、(d)の高振動数域、(c)回転で大きいことが分かる。また、(a)、 (d)では、アスペクト比が小さい方が加振直交方向の側面積が大きく なるため、付加質量効果がより大きく表れている。簡易評価式では、 この側面のインピーダンスを補正係数 $\gamma を$ 用いて算定しているが、こ の係数は準静的解に基づき推定されているため、高振動数域での精 度が不十分である。同様の理由で、アスペクト比が大きくなると (b) 上下の実部で精算解との対応が悪くなったため、 $0.3 \leqq c / b \leqq 3.33$ 程 度が適用可能な範囲となる。一方、(c)では実部、虚部ともにアスペ クト比変化の傾向は捉えられているが、アスペクト比が 0.5 や 2.0 を超えて細長い形状になると、精算解との対応が次第に悪くなって いく。以上から、アスペクト比に関しては全体として $0.5 \leqq c / b \leqq 2.0$ 程度を本方法の適用範囲と寸る。なお、(a)については、今回検討対 象とした $0.1 \leqq c / b \leqq 10.0$ の範囲でアスペクト比の変化によって精 算解と対応が悪くなる傾向は見られなかった。

図9に埋込み深さ比を、図10にアスペクト比をパラメータとした、 簡易解[2]で使用するドライビングフォースの比較結果を示す。ここ では簡易評価式(27)、(28)の妥当性を検討することから、ドライビ ングフォースの計算には、精算解のインピーダンスを用いている。 両図の(a)水平は、精算解と良く対応しているが、(b)回転は、準静的
值は一致するものの、埋込み深さ比が1を超えて大きくなるにつれ て実部、虚部ともに徐々に対応が悪くなる傾向が見られた。したが って、これを用いて基礎入力動を計算した場合には、式(22)から回 転ドライビングフォースは水平動にも影響するため、水平、回転の 基礎入力動ともに精算解と対応が悪い結果となった。このことから、 簡易解[2]の適用範囲は、埋込み深さ比で1程度までと寸る。なお、 埋込みが深くなるとドライビングフォースの回転成分の対応が悪く なる理由として、式(28)では側面のインピーダンスを中心位置での み評価していること、その位置での地動変位を基礎深さ方向に対し て単純に平均化していることが考えられる。一方、図10のアスペク 卜比による影響は(b)の虚部にやや見られるが、簡易評価式でその変 化を概ね表現できていると言える。

図11に埋込み深さ比を、図12にアスペクト比をパラメータとした 基礎入力動の比較結果を簡易解[1]、[2]について示す。また、図13 に地震波の入射角をパラメータとした基礎入力動の比較結果を簡易 解[1]について示寸。

図11 13の簡易解[1]では、(a)水平動や(c)䃿じれ動で值が0となる 振動数がある。これは式(15) (19)で分かるように、解が実数あるい は純虚数であり、インピーダンスを必要としない簡便な手法である ことに起因する。また、図11の(a)水平動については、簡易解[2]は 精算解と良く対応していることが分かる。(b)回転動では、簡易解[1] は、ピーク振動数が精算解に比べ高振動数となり、そこでは過大評 価となる傾向が見られる。簡易解[2]は、埋込みが浅い場合はやや大 きめの評価、深い場合には過小評価となっているものの、概数傾向 は捉えられている。簡易解[2]の回転動でこのような傾向になる主な 要因としては、図 $9(b)$ のドライビングフォースの回転成分の実部が、 精算解と比較して、埋込み深さが増すとともに小さくなっていくこ とが挙げられる。

図12により、簡易解は[1]、[2]どちらもアスペクト比による傾向 を概㸚捉えられている。

図13より、(a)水平動では、值が 0 まで落ち込むものの、精算解の $2 つ$ 目のピーク高さは捉えられている。(b)回転動、(c)ねじれ動では、 精算解と比較してピーク振動数で過大評価である点は図 11 と同様 の傾向であるが、入射角が増すことにより回転動が減少し、ねじれ 動が増加する傾向を十分捉えることができている。

以上より、今回検討した範囲では簡易解[2]は実用に供しうる簡易 評価法であり、また、簡易解[1]もある程度傾向を捉えることができ たと言える。

\section{5. まとめ}

本論では、 2 種類の基礎入力動の簡易評価法を新たに提案した。 簡易解[1]では埋込夕基礎と地動との幾何学的な関係から、簡易解[2] では地表面基礎のインピーダンスを出発点として埋込み基礎のイン ピーダンスを簡易的に作成し、それを地動への重みとして基礎入力 動を評価した。精算解との比較では、簡便性を考慮すると、両評価 法とも十分な精度を有する結果が得られた。簡易解[1]は、解が関数 の形で表されるために、設計の初期段階での傾向把握に有用と思わ れる。簡易解[2]は、比較的精度良い解であることに加え、用いた分 離・足し合わせの手法は、様々な条件に適用可能であると考えられ る。今後はさらなる簡便性を志向するとともに、基礎を分離し再度 


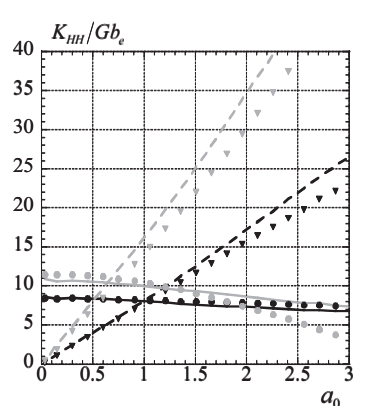

(a) 水平

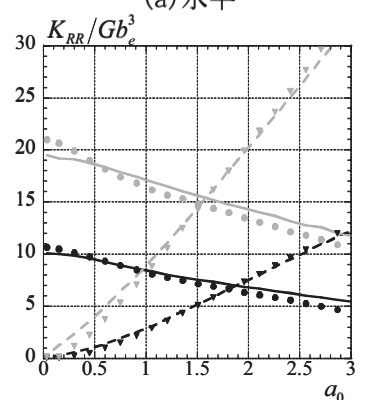

(c) 回転

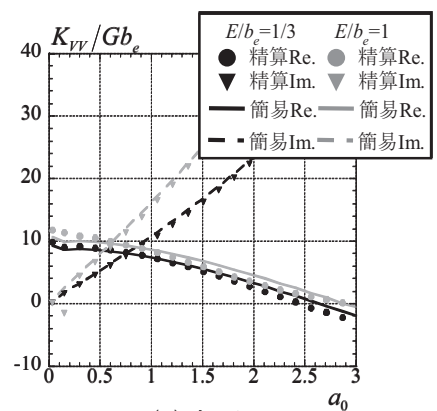

(b) 上下

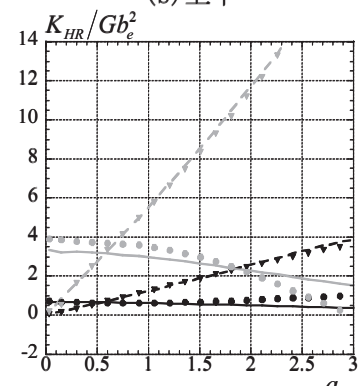

(d) 水平一回転連成

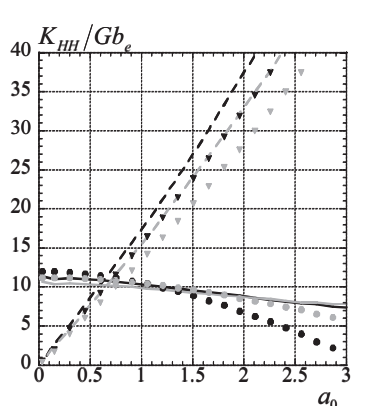

(a) 水平

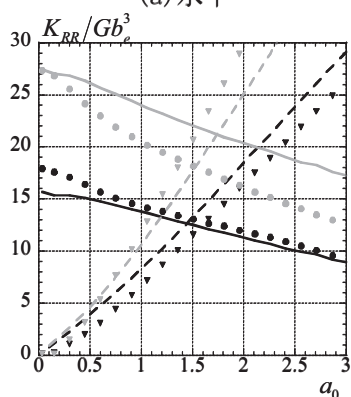

(c) 回転

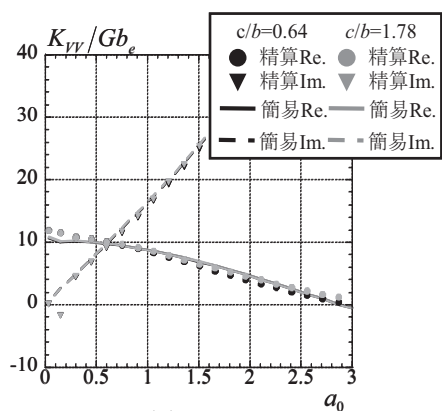

(b) 上下

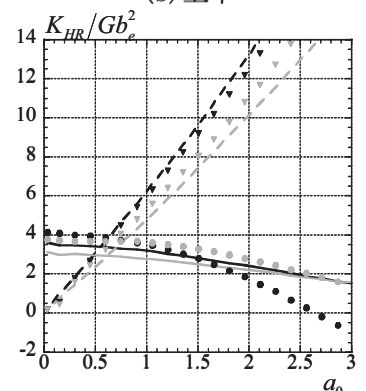

(d) 水平一回転連成

図 7 簡易解[2]に用いる埋込み深さ比によるインピーダンスの比較 図 8 簡易解[2]に用いるアスペクト比によるインピーダンスの比較

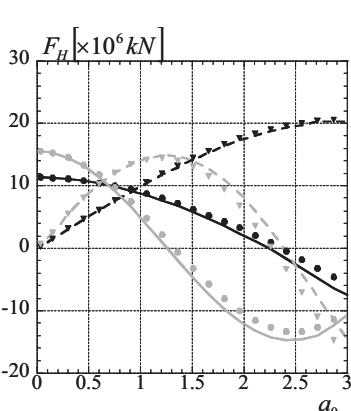

(a) 水平 $(c / b=1)$

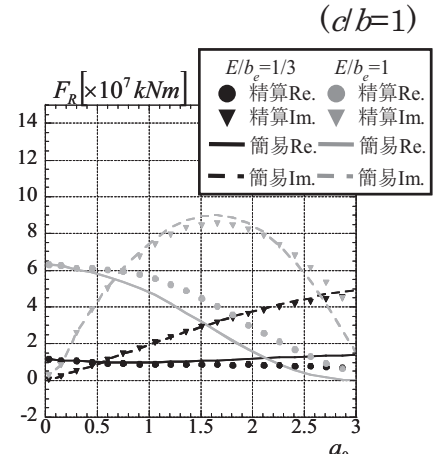

(b) 回転

図 9 埋込み深さ比によるドライビングフォースの比較

$(c / b=1)$

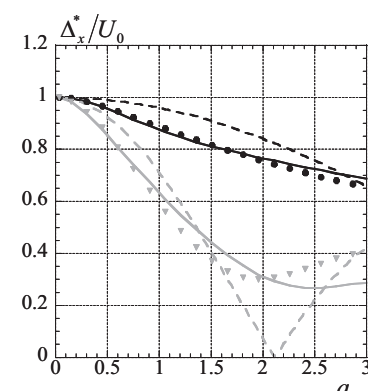

(a) 水平動

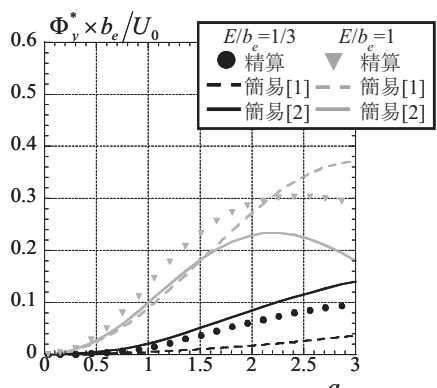

(b) 回転動 $a_{0}$

図 11 埋込み深さ比による基礎入力動の比較 $\quad(c / b=1)$

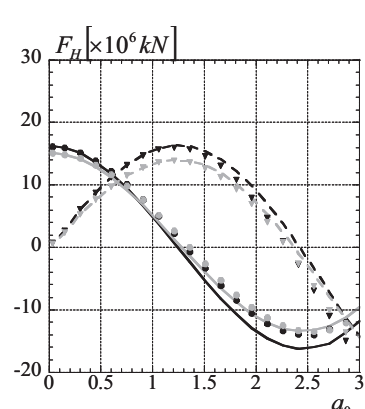

(a) 水平

$\left(E / b_{e}=1\right)$

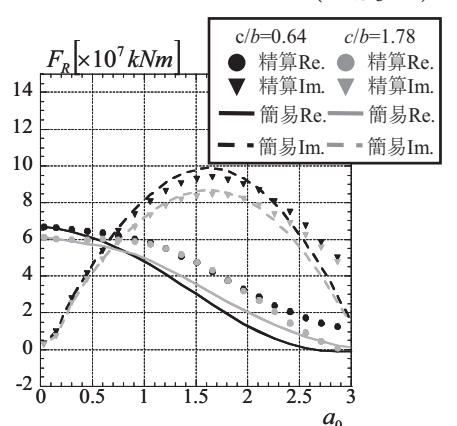

(b) 回転

図 10 アスペクト比によるドライビングフォースの比較

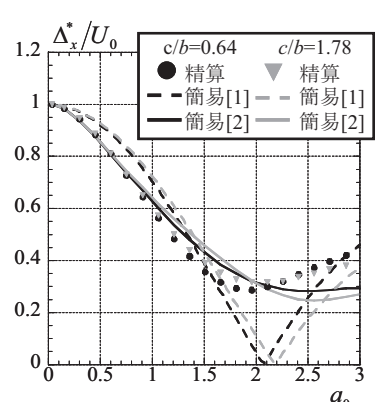

(a) 水平動

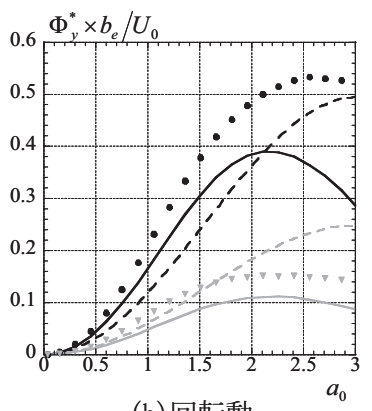

(b) 回転動

図 12 アスペクト比による基䃈入力動の比較 $\left(E / b_{e}=1\right)$

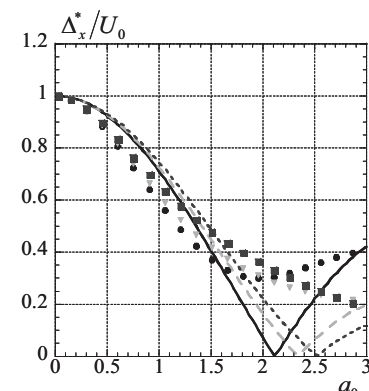

(a) 水平動

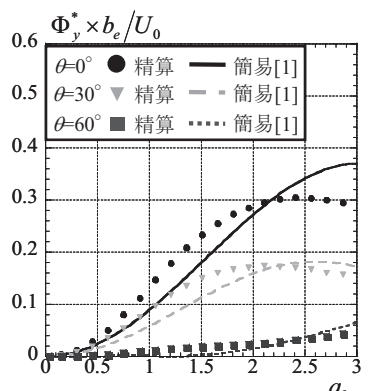

(b) 回転動

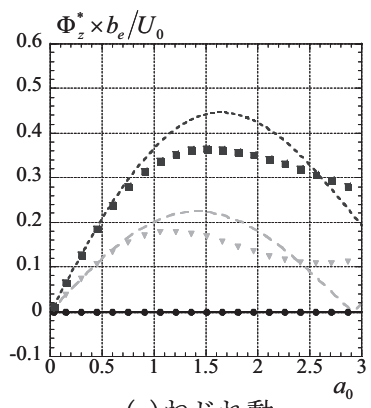

(c)ねじれ動

図 13 地震波入射角による基礎入力動の比較 $\left(c / b=1 、 E / b_{e}=1\right)$ 
必要な要素を足し合わせて評価する利点を活かせる不整形基礎や多 層地盤への展開、杭基礎やパイルドラフト基礎など別の基礎形式へ の応用を視野に、実設計で活用しや寸いよう改良をしていく予定で ある。

\section{参考文献}

1）宮本裕司ほか：2004 年新潟県中越地震での地震動と建物応答に関する研 究(その 1 その 3)、日本建築学会大会学術講演梗概集、B-2、pp.456-460、 2006.9 .

2) 山原浩 : 地震時の地動と地震波の入力損失(第 1 報)、日本建築学会論文報 告集、第 165 号、pp.61-66、1969.11

3）山原浩 : 地震時の地動と地震波の入力損失(第 2 報)、日本建築学会論文報 告集、第 167 号、pp.25-30、1970.1

4）石井清、山原浩 : 大型地下タンクの実測記録による地震波の入力損失の 検討、日本建築学会論文報告集、第 312 号、pp.54-62、1982.2

5）安井譲、井口道雄、赤木久真、林康裕、中村充：1995 年兵庫県南部地震 における基礎有効入力動に関する考察、日本建築学会構造系論文集、第 512 号、pp.111-118、1998.10

6）小島宏章、福和伸夫、飛田潤：强震観測・常時微動観測に基づく中低層 建物の入力損失効果に関寸る研究、日本建築学会構造系論文集、第 587 号、pp.77-84、2005.1

7）井口道雄、宇波桃子、安井譫、箕輪親宏 : 大型振動台基礎と周辺地盤の 同時地震観測に基づく基礎有効入力動、日本建築学会構造系論文集、第 537 号、pp.61-68、2000.11

8）川島学、井口道雄、箕輪親宏 : 地震観測に基づく基礎有効入力動の抽出 とその評価指標に関寸る研究、日本建築学会構造系論文集、第 615 号、 pp.85-92、2007.5

9) K. Yoshida : Fundamental Studies on Soil-Structure Interaction Problems, IRI Report, 95-01, 1995.3

10）泉洋輔、三浦賢治：限界耐力計算における基礎入力動評価の合理化に関 寸る研究、日本建築学会構造系論文集、第 616 号、pp.57-65、2007.7

11）国土交通省ほか：2007 年度版建築物の構造関係技術基淮解説書、2007.8

12）文学章：地盤と建物との動的相互作用における基礎形式・基礎形状・隣 接建物の影響に関寸る解析的研究、名古屋大学学位論文、2006.3

13) Iguchi, M. : An Approximate Analysis of Input Motions for Rigid Embedded Foundations, Trans. of A.I.J., No.315, pp.61-75, 1982

14）栗本修、井口道雄：実地震記録に基づく基礎入力動評価、日本建築学会 構造系論文集、第 472 号、pp.67-74、1995.7

15）栗本修、関崇夫：不整形な埋め込夕を有する基礎の動特性の簡便な評価 手法、日本建築学会構造系論文集、第 468 号、pp.19-26、1995.2

16）日本建築学会：入門・建物と地盤との動的相互作用、pp.55-61、1996

17）護雅史、福和伸夫、酒井理恵子、文学章：根入れを有する直接基礎にお ける側面と底面の動的相互作用特性とそれらの重合による地盤ばねの実 用的評価手法の検討、日本建築学会構造系論文集、第 626 号、pp.535-542、 2008.4

18）杉本浩一、護雅史、福和伸夫：基礎の浮上がりに伴う振動方向間の応答 連成効果を評価可能な地震応答解析モデルの構築、日本建築学会大会学 術講演梗概集、B-2、pp.683-684、2010.9

19）市川隆之、廣谷勉、中井正一、室井一夫、渡辺孝英：動的サブストラク チャー法による埋込みを有する構造物の簡易地震応答解析、清水建設研 究報告、第 42 号、pp.31-40、1985.10

（2010年10月 8 日原稿受理，2010年12月 6 日採用決定） 